\title{
Alexandru Ioniță (ed.), Imnografia liturgică bizantină. Perspective critice (,Studia Oecumenica", 13), Oradea-Cluj-Napoca, Edit. Presa Universitară Clujeană, 2019, 346p.
}

Imnografia liturgică bizantină Perspective critice

Alexandru Ioniță (ed)

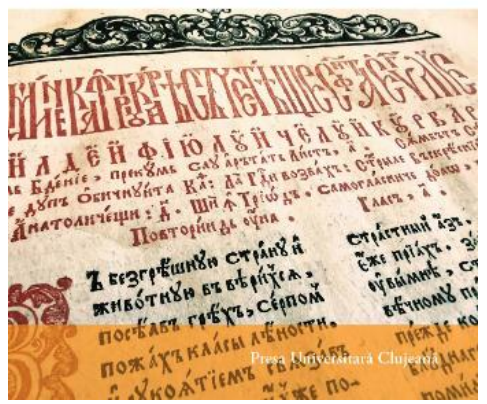

Structurat în două părți distincte, însă într-o strânsă legătură, volumul care reunește studii recente dedicate imnografiei liturgice bizantine, coordonat de părintele Alexandru Ioniță, reflectă preocupările unor importanți teologi contemporani.

Prima parte, intitulată generic Imnografia ortodoxă și anti-iudaismul (p. 11-120), are caracteristicile unui adevărat tur de forță în ceea ce privește un subiect care e mereu actual și care poate fi descris printr-un singur cuvânt: fanatismul. Sunt, din nefericire, tot mai multe situații în care simpla auzire a unor cuvinte scrise într-un anumit context și cu un rol precis să-1 determine pe credincios la atitudini ostile. În acest sens, profesorul Michael Azar, în primul studiu din volum, intitulat: „Matrice profetică și paradox teologic: iudei și iudaism în Săptămâna Mare și în ritualurile pascale din Biserica Ortodoxă" (p. 11-38) vorbește despre necesitatea înțelegerii corecte a textelor 
respective, concluzia autorului fiind aceea că, în momentul în care este vorba despre ,pasajele anti-evreiești, ele nu trebuie clasificate drept produse ale elanului anti-iudaic, mai degrabă decât produse ale întâlnirilor teologice cu Omul Dumnezeu, Autorul vieții Care S-a supus morții, care se minunează în mod repetat de răscumpărarea întregii omeniri, a evreilor şi a grecilor, prin cucerirea morții” (p. 38).

Profesorul Ioannis Mourtzios, autorul celui de-al doilea studiu al volumului, care a beneficiat de efortul traductologic al lui Alexandru Prelipcean, profesor la Catedra de Vechiul Testament al Facultăţii de Teologie din Tesalonic, în studiul intitulat: „Fenomenul antisemitismului în Biserica Ortodoxă. Texte liturgice ale Săptămânii Patimilor" (p. 39-51) adoptă o perspectivă interesantă atunci când, de pildă, preferă echilibrul normalității celui al fundamentalismului care, uneori, își face loc în comunitățile ortodoxe. Profesorul Mourtzios afirmă, de pildă, că: „în lumea creștină, îngăduința (non-relativizarea credinței religioase particulare) va trebui să cuprindă în modul ei de gândire, o apreciere pozitivă a diferenței celuilalt, o viziune a unei concepții religioase diferite" (p. 48).

Bogdan G. Bucur, de la Duquesne University, într-un studiu amplu (p. 52-77), pe care 1-a intitulat: „Retorica anti-iudaică din imnografia bizantină: contextualizare exegetică și teologică” vrea să arate că ,în primele comunități creștine, contextul pentru antiiudaismul vitriolic din Biblia Ebraică, din unele scrieri apocaliptice aparținând perioadei celui de-al Doilea Templu, și din Noul Testament [...] se schimbă treptat, trecând de la o acerbă polemică intra-iudaică la o polemică între o Biserică predominant a neamurilor și evrei” (p. 63). Faptul că uneori așa-numitele ,inovații în cult" reprezintă o stigmatizare nefirească a evoluțiilor imnografice normale, reprezintă pentru prof. Bucur o adevărată provocare de a le observa şi de a le demasca erorile printr-o afirmație importantă, anume că ,modificarea textelor și cutumelor liturgice ortodoxe nu este, în sine, nici greșită, nici fără precedent" (p. 77), astfel că Biserica Ortodoxă este invitată „să exorcizeze” 
„duhul anti-iudaic ce ne stă în prag şi caută să ne târască după el, pentru a ne întina liturghisirea și de a ne înghiți sufletește" (p. 77).

Monahia Éliane Poirot o.c.d., autoare a penultimului studiu din prima parte a volumului este cunoscută iubitorilor de texte teologice, între altele, pentru faptul că a reușit să ofere cititorilor de limbă română o excelentă monografie dedicată profetului Ilie Tezviteanul, publicată de părintele Ioan I. Ică jr. la editura Deisis din Sibiu. Studiul pe care îl propune aici monahia Éliane este intitulat „Permanența legământului și textele liturgice bizantine” (p. 78-94). Întrebarea din final, actuală, are în vedere o perspectivă actualizată cu privire la „datoriile” credincioșilor contemporani: să asumăm bogăția imnografică din primul mileniu care, în opinia distinsei autoare, va servi evanghelizării din cel de-al treilea mileniu în perspectivă eshatologică (p. 94).

Prima parte a volumului se încheie cu studiul părintelui Alexandru Ioniță, Cercetător Științific III la Centrul de Cercetare Ecumenică a Universității „Lucian Blaga” din Sibiu. Premisa de la care pornește autorul are în vizor studierea a trei capitole din Epistola către Romani care, probabil, reprezintă sursa de inspirație pentru unele creații imnografice. Studiul, intitulat „Vin vechi în burdufuri noi: Rom. 9-11 ca sursă de inspirație pentru unele creații imnografice" (p. 95-120) are în vedere pe de o parte relațiile dintre iudei și creștini iar, pe de altă parte, Biblia, privită ca element de inspirație a Liturghiei. „Îmbrăcate cu haina melodică bizantină și împletite cu efortul catehetic specific imnografiei ortodoxe acestea ar putea pătrunde mai ușor în «canonul» de învățătură creștină și liturgică, din care au lipsit prea mult timp" (p. 120).

A doua parte a volumului, puțin mai extinsă, reunește, sub titlul generic Biblie și Liturghie, șapte studii.

În primul rând, din nou, în traducerea domnului Alexandru Prelipcean, avem bucuria de a citi și în limba română ideile profesorului Derek Kruger de la Universitatea din Carolina de Nord, intitulat „Biblia penitențială și Canonul cel Mare al lui Andrei Criteanul" (p. 123-178). Profesorul Kruger afirmă că „scopul cercetării biblice a lui Andrei este de a inspira pocăința” (p. 126). Pentru realizarea acestuia, Sfântul Andrei preferă să utilizeze 
metoda exegetică prin care el este un autor original deoarece ,pare să folosească puțin din tradițiile comentariilor primare, incluzând predicile anterioare la caretea Facerii”' (p. 127). Iarăși, studiul arată că, în epoca lui Andrei Criteanul, ,în cadrul lecționarelor bizantine, cea mai mare expunere a Vechiului Testament avea loc în perioada Postului Mare și provenea din trei cărți: Facerea, Proverbele lui Solomon și Isaia. În cadrul Postului mare, în timpul săptămânii, citirile din aceste cărți se făceau conform unui sistem de lectură continuă, deși niciuna dintre aceste cărți nu era citită în întregime; când Postul cel mare avansa, o mare parte din fiecare era abandonată lecturii” (p. 148). În concluzie, ,Marele Canon aruncă o lumină asupra instrumentelor prin care aparatul instituțional al Bisericii a subliniat subiectivitățile individuale... Andrei a chemat implicit pe toți să se vadă prin lentila penitențială a Scripturii. Întreaga istorie biblică are ca rezultat conștiința condamnată și aceasta este învățătura lui către turma sa" (p. 178).

Protopresbiterul Dr. Doru Costache, Lector senior al „St. Cyril's Coptic Orthodox Theologica College", o instituție membră a Sydney College of Divinity, Australia, propune un studiu interesant: „Ințelegeri bizantine: Cartea Facerii, teologie și spiritualitate în Canonul cel Mare al Sfântului Andrei Criteanul” (p. 179-216). După cum afirmă autorul încă de la început, studiul reprezintă o parte din cercetarea laborioasă, de lungă durată, a „diverselor percepții tradiţionale a capitolelor 1-3 din cartea Facerii" (p. 179). Este demn de reținut în opinia mea informația potrivit căreia ,tradiția bizantină a canonizat maniera sa de citire a Scripturii în forma creativității imnografice" (p. 184). De aici rezultă, afirmă părintele Costache, faptul că ,indiferent cât de stranie poate părea această manieră interpretativă unor cititori preocupați de obiectivitatea mesajului biblic, poemul pune în lumină, fie și indirect, prin maniera sa în care prezintă lucrurile, faptul că în Scriptură nimic nu este reductibil la informație. Totul în Scriptură cere subiectivizarea, țintind către formarea personală şi transformarea holistică, duhovnicească a cititorilor" (p. 199).

Următorul studiu, întocmit de Alexandru Prelipcean, asistent asociat la Facultatea de Teologie Ortodoxă „Dumitru Stăniloae” din 
Iaşi, este intitulat: „Imaginea lui Moise în condacele Sfântului Roman Melodul. Scurte remarci” (p. 217-239). Cu toate că, după cum aflăm de la început, ,primul care a dezvoltat într-o manieră analitică imaginea lui Moise este Roland Joseph Reichmuth" (p. 217), urmată de contribuțiile importante ale altor cercetători: José Grosididier de Matons (p. 218) și, nu în ultimul rând, contribuţia semnificativă a profesorului Ioannis G. Kourembeles (p. 218), studiul propus aici arată că această ,imagine” a lui Moise este ,,pe de o parte... tipologie, iar pe de altă parte, relația de dependență dintre poetul eclesiastic și alți Părinți anteriori lui” (p. 220) sunt luați ca sursă de inspirație de Roman Melodul, pentru condacele pe care le alcătuia. Concluzionând, dl Prelipcean afirmă că „Pentru marele poet eclesiastic, Moise ca protagonist al condacelor sale ajută la susținerea subtilităţilor teologice (= dogmatice), și implicit, la susținerea vieții eclesiastice dinamice în Hristos, în timp ce anumite elemente biografice ale lui Moise, înțelese ca realitate istorică, sunt identificate $\mathrm{cu}$ acel modus vivendi al bizantinilor, acest «Israel al lui Dumnezeu»" (p. 239).

O altă contribuție, cea a profesorului Andrew Mellas, de la Sydney, Australia, este tradusă în volum cu acordul redacției jurnalului Phronema de către dl Alexandru Prelipcean. Profesorul Mellas se concentrează pe emoțiile liturgice prezente în imnografia bizantină. De aici și titlul: „Emoții liturgice în imnele bizantine: condacul «La biruința Crucii» al lui Roman Melodul" (p. 240-269). Cu toate că este evident, după cum afirmă și autorul, că „lumea Bizanțului nu este lumea noastră” (p. 244), totuși, un studiu dedicat subiectului din titlu se impune cu urgență pentru că „literatura existentă despre emoții în Bizanț a trecut în mare parte cu vederea modul în care imnele au dramatizat sentimentul și au abordat emoțiile ca pe niște creații «ideatice», mai degrabă decât fenomene încarnate" (p. 245). Pilonii principali au fost mereu pentru bizantini formate din trio-ul: Scriptură, Liturghie, imnografie, ultimele fiind ,scenariile care i-au învățat pe oameni «cum să simtă, cum să-și exprime sentimentele, cum să gândească despre propriile lor sentimente și ale altora»" (p. 249). Condacul pe care îl analizează profesorul Mellas reprezintă un fel de 
paradox: deși „evocă nostalgia credincioșilor pentru Paradis, aceștia refuză această nostalgie printr-o prismă complexă a unei comuniuni eshatologice, în care personaje biblice invită adunarea liturgică să cânte cu Adam, Eva și cu tâlharul și, astfel, să trăiască din perspectivă liturgică" (p. 269).

Pentru că este vorba în principal despre textele penitențiale, este foarte potrivit un alt studiu al domnului teolog Alexandru Prelipcean, intitulat „Numirile lui Hristos în textul Prohodului Domnului" (p. 270-283). Studiul, publicat inițial în limba engleză, se raportează pe de o parte la așa-numitele „numiri biblice ale lui Hristos" care arată, dacă mai era nevoie, că autorul cunoștea foarte bine textul Scripturii (p. 282), însă, aceste imagini ,plastice sau poetice nu sunt independente de textul scripturistic sau de influența Sfinților Părinți în creionarea dogmelor Bisericii” (p. 283).

Penultimul studiu din volum, este o cercetare laborioasă întocmită de părintele Cosmin Pricop de la Facultatea de Teologie Ortodoxă Justinian Patriarhul din București, pe care autorul 1-a intitulat: „Receptarea Scripturii în textele liturgice. Studiu de caz: slujba ortodoxă a Logodnei” (p. 284-304). Autorul afirmă că, din moment ce ,atât anamenezele cât și epiclezele din textele liturgice se orientează după istoriile sau experiențele lui Dumnezeu cu oamenii (și invers)" (p. 304), este necesară o distincție clară între textul biblic și evenimentele povestite de acesta pentru că, desigur, în definitiv ,toate aceste mesaje nu au altceva în centrul lor decât interacțiunea lui Dumnezeu cu oamenii” (p. 304).

Stelian Pașca-Tușa, lector la disciplina Vechiul Testament, în cadrul Facultății de Teologie din Cluj-Napoca propune un studiu interesant: „Psalmul 119 [118] - elogiu liric al Torei: de la Scriptură spre Liturghie" (p. 305-346). Textul acestuia este relevant pentru că ,într-o lume nesigură, în care nelegiuirea celor mândri șia întrecut limitele, iar abaterea de la Lege și părăsirea ei a înmulțit numărul celor păcătoși, psalmistul își găsește alinarea și stâlp de nădejde în cuvântul lui Dumnezeu" (p. 325). Şi aceasta deoarece ,întruparea cuvântului scripturistic este mijlocită de un cadru liturgic” (p. 346). De aceea ,cultul doxologic al Bisericii creștine a fost marcat încă din structurile lui primare de cântarea psalmică. 
Mărturiile patristice privitoare la modul în care erau utlilizați psalmii în liturghia creștină sunt edificatoare" (p. 346).

Important pentru liturgiști și, deopotrivă, pentru bibliști, ca şi pentru toți iubitorii de texte patristice și pentru cei interesați de evoluția cultului, de aspecte legate de alcătuirea textelor poetice emblematice, specifice Răsăritului ortodox, volumul se impune ca lectură esențială și de neocolit pentru viitoare cercetări care, sperăm, vor duce mai departe munca și rigoarea celor ce s-au ostenit în realizarea acestei lucrări de excepție pe care, firește, o recomandăm ,spre lectură ziditoare de suflet” cu toată căldura.

\author{
Pr. Claudiu Ioan Coman \\ Facultatea de Teologie Ortodoxă \\ „,Dumitru Stăniloae” din Iaşi
}

